\title{
Heidegger on The Nature of Truth
}

\section{Mario Garitta \\ University of Kansas}

Perhaps there are no more central themes in philosophy then those which involve the nature of truth. Yet surprisingly, the issue regarding the nature of truth itself, an issue which in its essential character impinges upon every other issue and problem has at least in regard to its substantive character achieved scant attention on the part of our major modern philosophic traditions. While the issue of truth has been the object of much focus in the analytic tradition, this focus has almost always been deflationary in approach. Following Tarski these redundancy or disquotational accounts embody a conviction that at bottom truth has no substantive content.

The neglect to seriously reflect upon the substantive character of truth is even more surprising in light of the contemporary polarization of our philosophical world into two all but mutually exclusive modes of thinking and discourse. While again and again this polarization is lamented as destructive to the integrity of philosophical thought, it is not entirely clear what the ultimate roots of this dichotomy are or how it might be effectively transcended. While the ambiguity of this situation defies any simple solutions it might simultaneously provide inspiration for experimental thinking. In such a spirit a primary reflection upon the nature of truth in our human experience might effectively provide a passageway out of the current impasse in which philosophy finds itself.

In a philosophical context, a context which is present albeit in different ways in both the analytic and the continental traditions, the issue of truth is unique in its power to wrest attention away from peripheral concerns toward the integrity of a vital center of meaning. Simply expressed, the issue of truth in human experience has universal significance for thought, even if it is not simply and only 'truth' which embodies this significance, but anything we 
can know or name as truth, even 'meaning' and 'significance' themselves.

The issue of truth in human experience has been a persistent theme throughout the work of Martin Heidegger. Since Heidegger's collected work consists of an enormous five hundred volumes, a responsible attempt to treat the topic of truth in a general way in Heidegger's work as a whole is clearly impossible within the scope of a small paper. Moreover given the complexity of the issue of truth itself, coupled with its interconnectedness with the meaning of Being in Heidegger's work, a full exposition of Heidegger's concept of truth would itself be too unwieldy to manage. How then to proceed?

We must begin with a forthright recognition of the problematic character of our enterprise. Our goal is to render Heidegger's understanding of truth intelligible to an analytic audience largely unfamiliar with his language and methodology. What is presupposed here is that Heidegger has indeed achieved a fundamental understanding of the character of truth and one which is enormously significant in any philosophical context. Yet this claim will require justification. Inevitably when attempting to justify claims across philosophical traditions, such endeavors turn on the issue of methodology. Yet Heidegger's phenomenological, historical, hermeneutical methodology is both complex and, at least within the context of analytic philosophy, problematic in its unfamiliarity. An attempt to fully justify this methodology would require at least three separate proofs, to say nothing of the attempt to demonstrate the effectiveness of how these methods work together. To make a beginning we have selected one of these methods, the historical, and have made it the focal point of our examination. Accordingly our theme will be not simply Heidegger's concept of truth but an attempt to justify Heidegger's historical approach to the issue of truth.

While the issue of truth like that of Being is most often interwoven with the fabric of a general ongoing problematic in Heidegger's work, indeed as will become clear it is futile to attempt to surgically separate the two issues. Nevertheless, from a purely structural point of view our task is ostensibly made easier by the fact that Heidegger has addressed the issue of truth in at least four 
separate places in his work. The first of these is in section 44 of Being and Time. The second is in a small essay entitled "Vom Wesen den Warheit," ("On the Essence of Truth"). Up until recently these were the two primary sources for an understanding of Heidegger's theory of truth. In the early 80 s this situation changed with the publication of two series of lectures which Heidegger presented shortly after the publication of Being and Time. The first was from a lecture course in 1927 under the title The Basic Problems of Phenomenology. In sections 295-320 Heidegger once again directly addresses the issue of truth in human experience along with concomitant topics such as 'significance,' 'assertion' and 'meaning.' The second was from a lecture course given in 1928 and published under the title The Metaphysical Foundations of Logic. The publication of The Basic Problems of Phenomenology and The Metaphysical Foundations of Logic, along with another series of lectures delivered shortly before the publication of Being and Time in 1927 and released under the title History of the Concept of Time, have been highly significant events for Heidegger scholarship in America.

Through these series of lectures a new generation of scholars has come to understand firsthand what the actual students of Heidegger such as Walter Biemal had told us long ago, namely that like Hegel and Kant before him Heidegger, notoriously abstruse in his written texts, was likewise remarkably clear and lucid in his classroom presentations. ${ }^{1}$ Since there is often a striking sectionby-section correspondence between these lectures and Heidegger's written works, they have come to be employed as the definitive reference sources for Being and Time. The method of exegesis of Being and Time with close textual support from Basic Problems and History has been fully utilized in two of the latest and most important works of Heidegger scholarship: Hubert Dreyfus's Being-in-the-World and Richard Polt's Heidegger. The former, a landmark work in Heidegger studies, became the first to employ this method and in it the author acknowledges the profoundly important role that that Heidegger's early lectures have played in what has become the state-of-the-art commentary on Being and Time. 
The impact upon our understanding of the early Heidegger lectures has been so marked that just as we have since Richardson ${ }^{2}$ routinely though not without ambiguity separated the Heideggerian body of work into Heidegger I and Heidegger II, so it is now tempting to divide Heidegger commentary into pre- and post-early lecture discovery periods, though needless to say these two divisions in no manner overlap. Significantly enough, the postearly lecture Heidegger is more palatable in an Anglo-American context. If the reluctance to fully encounter Heidegger in the AngloAmerican world can in part be attributed to Heidegger's own obfuscating language and to the charge initiated historically by Rudolf Carnap that such language betrays fundamental logical confusions then the post- early lecture Heidegger is more conceptually clear because he is more linguistically precise. Again and again we are discovering that the most obscure and ambiguous aspects of Heidegger at bottom express thoughts which are clear and insightful albeit not immune to critical challenge. Neither should the actual text of Heidegger be immune to such challenges even within a Heideggerian context. Indeed the early lectures are now employed to the extent of correcting fundamental inconsistencies within the text of Being and Time. ${ }^{3}$

Notwithstanding the indisputably important role these new series of lectures have had on Heidegger scholarship generally in and through their influence on interpretation of Being and Time, a practical question emerges at this point: Can one simply draw freely from the above texts in an attempt to construct a unified theory of Heidegger's historical approach to truth? Any attempt to do so must counter certain obstacles. The first is that the most likely source for additional material, History of the Concept of Time has no section corresponding to section 44 of Being and Time, although the issue of truth is directly discussed there in an abbreviated form. A more complete discussion is instead found in Basic Problems of Phenomenology (295-320). Why should this fact prove problematic? As indicated earlier utilization of Basic Problems for clarification of issues in Being and Time has become indispensable in Heidegger scholarship. Yet some caution is still in order. 
In the table of contents of Being and Time Heidegger indicates that the entire project will consist of two parts. Each of these is in turn subdivided into three sections. The only sections which are actually contained in Being and Time are sections one and two of part one, roughly $1 / 3$ of the entire project. All the rest has not been published or written, at least not in the original form in which it was conceived. In a footnote to the beginning of Basic Problems Heidegger tells us that this book contains the material which was announced as section three of part I of Being and Time. Hence we should not expect that Basic Problems simply reiterates the material contained in Being and Time, or rather to the extent that the material is repeated it is done so in a unique Heideggerian sense, in the sense of wiederholen. It is in this sense that Being and Time is altogether a retrieval. It is a retrieval both of the roots of Western culture and of something which takes place in experience all the time. Specifically section three was meant to continue the retrieval begun in section two of the analysis of Dasein but now from the point of view of temporality.

Ultimately any attempt to utilize both Being and Time and any post Being and Time writings must come to terms with the thorny issue of the Kehre (turn) in Heidegger's thinking. If indeed Heidegger's thinking underwent a fundamental change after Being and Time, then the exercise of lumping together pre and post Being and Time writings to form a unified doctrine on a particular issue, for example, truth would involve quite a precarious move. How can this situation be effectively handled? While the issue of 'the turn' in Heidegger is a tremendously complicated affair one fact remains clear, namely that where there is a transition in Heidegger's thinking it is one which takes place within an overarching continuity. So much is this the case that it can be said that the necessity of a turn is already written into the table of contents of Being and Time itself. Once we are thoroughly grounded in the logistics of the Heideggerian project, once the primacy of the Seinfrage as well as the priority of Dasein is understood, then the Kehre no longer appears as an obstacle to the exegesis of the Heideggerian text. To be sure, fundamental differences as they affect our attempt to formulate a unified theory of Heidegger's historical approach to truth must be noted. 
What then is Heidegger's historical method and how is it applied in attempting to formulate the essential character of truth? While there are unique aspects to Heidegger's historical approach to philosophy, in essence the historical-philosophical method itself maintains there is an intrinsic connection between our philosophical history and the ongoing creative process of philosophical thinking itself. Thus, practitioners of an historical method deny that a necessary separation can be made between our philosophical history and ongoing philosophical research. This is to say that practitioners of an historical method deny that philosophical issues should or can be explored in a purely analytical manner with minimal reference to their historical origin development and situatedness within an original context of meaning. As a paradigmatic historical thinker one would expect Heidegger's exploration of the issue of truth to begin with the traditional concept of truth as adequation, and whether we turn to Being and Time, to Basic Problems, or to "On the Essence of Truth" we are not disappointed in this expectation.

Heidegger's most complete discussion of the historical dimension of the nature of truth is contained in "The Essence of Truth." There he engages in an extended commentary of both the traditional Aristotelian concept of truth and its medieval reformulation. Yet from a more critical perspective we should ask: why would an essential or fundamental reflection on the nature of truth at all require an historical approach? Why not rather simply treat the issue in terms of the requisite features of truth in a manner common to both the analytic and the phenomenological methods? The fact that Heidegger in at least three of his extended treatments approaches the issue historically indicates that such a move is intrinsic to his method. Yet we might ask: why is the content of what has been thought about the character of truth in the past essentially connected with the essence of truth itself? In attempting to answer this question it is important to recognize from the start that Heidegger's historical method is not practiced in isolation from either the phenomenological or hermeneutical methods. Although Heidegger's reflections intrinsically involve explorations into our philosophical past, his essential starting point is hermeneutical. The hermeneutical method originally began as an 
attempt to find a method adequate to the interpretation of sacred texts. With time this enterprise of thought branched out to include literary and philosophical texts as well. The fundamental presupposition of hermeneutics is that the empirical scientific method is not adequate to an interpretation of texts within the human sciences or geisteswissenshaften. Heidegger's use of the method of hermeneutics represents what might be called the 'third phase' of the development of the method. In this phase not only texts but experience itself becomes the object of interpretation.

With its explicit acceptance of the circular character of all interpretation the hermeneutical method stands in marked contrast to the phenomenological which aims to make philosophy in Husserl's words "a rigouous science." Yet even though Being and Time is dedicated to Husserl, Heidegger's former teacher, it is clear that Heidegger rejects Husserl's ideal of a philosophy which can be scientific. Nevertheless Heidegger's approach is deeply phenomenological. The issue of the relationship between Husserlian and Heideggerian phenomenology is a complex one. One thing they share in common is a rejection of a speculative approach to philosophy in favor of faithfulness to the data of experience. In this manner the hermeneutical and phenomenological methods although traditionally opposed, as practiced by Heidegger coincide at least at one point. Both Heideggerian phenomenology and hermeneutics posit experience as the primary object of philosophical research.

Heidegger's opening section of "On the Essence of Truth" is entitled: "The Usual Concept of Truth." Thus he begins not simply with an historical fact but with the fact that this historical concept, namely truth as adequation, represents as well our prevailing concept of truth. This fact raises an essential question for thought: has the traditional concept of truth as adequation prevailed because it represents the essence of truth itself, or has our prevailing concept of truth at least to some extent been inherited in the form of a philosophical tradition?

At this point something of the sense of Heidegger's historical method should begin to emerge. In a minimal sense the historical method can be understood as involving an exercise in critical reflection. It aims to insure that the credentials of our inherited 
concepts are subjected to critical examination regarding their authenticity. Without such historical awareness it is all too easy for unexamined presuppositions to slip through the checkpoint of critical awareness. Why not then simply examine our presuppositions more carefully? Such an exercise could obviously be carried on with little or no historical awareness. This might constitute an overwhelming objection against an historical approach were it not for the fact that presuppositions which are meant to be examined occur within anterior frameworks which are themselves presupposed.

Why not then simply examine the second set of presuppositions, or rather identify, in the case of each philosophical issue, what the total set of presuppositions is? Clearly this is a method which is followed by most analytic philosophers as well as by pure phenomenologists. Such a method involves a commitment to philosophy as a kind of presuppositionless science. Heidegger would undoubtedly reject this kind of paradigm for philosophy and he would do so in part on the basis of considered objections regarding both the desirability as well as the possibility that philosophy can ever achieve the status of science. Much of the earlier sections of History of the Concept of Time, as well as corresponding sections of Being and Time, involve a critique of the kind of disinterested knowledge which would make a purely analytical approach to philosophical issues possible. ${ }^{4}$ One essential aspect of this critique contains the insight that the essential parameters in which understanding operates, the social, cultural, historical frameworks which constitute a given context of understanding at any time, are not simple presuppositions which can be made fully explicit in the manner of steps in a logical proof. Thinking in any given era takes place within a 'space' of possibilities which is historically constituted.

Paradoxically one of the fundamental aspects of Heidegger's historical method is that through its application we are offered the possibility of a detailed kind of understanding of the limitations of any particular tradition including our own. Philosophical traditions limit understanding as well as provide access to the kind of insight which is universal. In a reflection upon the relation of philosophical analysis to tradition in an early section of Being and 
Time, Heidegger writes: "Dasein simultaneously falls prey to the tradition of which it has more or less explicitly taken hold."' On the next page Heidegger continues: "When tradition thus becomes Master, it does so in such a way that what it 'transmits' is made so inaccessible, proximally and for the most part, that it rather becomes concealed. Tradition takes what comes down to us and delivers it over to self evidence; it blocks our access to those primordial 'sources' from which the categories and concepts handed down to us have been in part quite genuinely drawn."6 Given the manner in which philosophical traditions constitute the very frameworks in which thinking operates, historical awareness can then be seen as an intrinsic aspect of critical philosophical thinking.

In a masterful deconstructionist interpretation of Heidegger, Reiner Schurmann attempts to articulate Heidegger' understanding of how this 'space' of possibilities opened up in any given era is historically constituted. "How does it happen that a Duns Scotus, although surnamed Doctor Subtilis, could write neither a critique of pure reason nor a genealogy of morals? How does it happen, in other words that, a domain of the possible and the necessary is instituted, endures for a time and then cedes under the effect of a mutation? How does it happen?" "Schurmann's questions, although they are meant to be merely a starting point of his analysis in Heidegger on Being and Acting, wonderfully illustrate the correctness of Heidegger's insight into how the frameworks in which thinking operates in any given era are constituted by presuppositions which can never be made fully explicit. In historical hindsight, we intuitively know that it was not possible for Duns Scotus to write a critique of pure reason. This fact alone gives support to Heidegger's concept of the historical constitution of the space of possibilities of thinking which it is meant to explain.

Given the foregoing considerations, an historical approach to philosophical issues would seem at the very least to be a plausible method of exercising critical awareness with regard to philosophical issues. In the absence of this method the analytic philosopher-phenomenologist must by necessity progress from the point of simply exercising critical awareness with regard to fundamental presuppositions as they effect a philosophical issue 
under consideration to an enterprise which defines, even consumes, the character of questioning itself. In the necessity embodied in such a methodology of tracing assumptions back to an original presuppositonless ground, essential insights such as could have been provided by an historical method have been lost. Indeed the analytic philosopher would be closed to such insights. Philosophy becomes transformed into a method of pure analysis.

In defense of the analytic philosopher it might be said that the presupposition of philosophy as science does not involve the necessity of following a chain of reasoning back to a selfauthenticating ground in the case of every topic under consideration, but rather that apodictic certainty merely characterizes the ideal of philosophy itself. Philosophy practiced after the paradigm of science clearly allows for its practitioners to 'stop' and focus at any step along the line of a chain of reasoning. Heidegger could easily acknowledge this point but would nevertheless point out that the precise point where analysis is focused, the philosophical problems which occupy us for generations at a time are, in large measure historically determined. Here a case in point would be the modern focus upon epistemological questions, the 'problem' of the existence of the external world, of 'other minds,' etc. In Being and Time, and more so in Basic Problems, Heidegger works hard to 'lay bare' the ontological foundations which led to this very particular modern problematic. ${ }^{8}$ Whether or not Heidegger's analysis is correct is a complex question. The fact that Wittgenstein, operating with a purely analytical method largely concurs with Heidegger on the manner in which modern epistemological issues are pseudo problems, ${ }^{9}$ has done much to enhance the status of Heidegger in the Anglo-American philosophical world. But whether or not Heidegger's analysis is entirely correct, at the very least his thinking indicates that philosophical problematics have an historical basis, and that therefore an historical method can be relevant to their analysis.

At this point there is no better way to continue to illustrate the character of Heidegger's historical method then to see how it is concretely employed in "On the Essence of Truth." Let us then refocus upon our original question of whether the traditional 
concept of truth as adequation represents the essence of truth itself, or to what extent this concept has prevailed because it has been inherited in the form of a philosophical tradition.

If these two possibilities were mutually exclusive then the question would lose much of its force. Philosophical traditions are not simply inherited en masse oblivious to critical examination. However, Heidegger never doubts that truth as adequation represents a legitimate aspect of our human experience of truth. Thus he is not offering us a new and original theory of truth at all but one which attempts in a Kantian manner to make fully explicit the ontological foundations of truth as adequation. In Being and Time he writes: "Our analysis takes its departure from the historical conception of truth and attempts to lay bare the ontological foundations of that conception. ${ }^{10}$ In doing so Heidegger notes that the traditional definition of truth as veritas est adaequatio rei et intellecuts can be taken in two ways: either as the correspondence of intellect to thing or the reverse. To eyes less historically discerning the distinction might seem superfluous, even spurious. The two statements "truth is a conformity of intellect to thing" and "truth is a conformity of thing to intellect." are ostensibly equivalent. Yet Heidegger insists that these two formulations are by no means the same even though they nevertheless share a concept of truth as conformity. The most recent medieval definition of truth is veritas as adaequatio rei ad intellectum (truth as the conformity of thing to intellect)."

By such a formulation the medievals understood the essential character of conformity, in terms of which truth is defined to be not simply the conformity of the human mind to what is real but the conformity of the created world to the divine intellect. It was God understood as the primary ontological ground of the created world, including the human intellect, which made possible truth as conformity between the human intellect and what is external to it. "Veritas as adaequatio rei (creandae) ad intellectum (divinum) guarantees veritas as adaequatio intellectus (humani) ad rem (creatum)" ( page 121). ${ }^{12}$

It is clear that Heidegger identifies 'correspondence between thing and intellect' as the medieval expression of adequation while 'correspondence between thing and intellect' is considered the 
paradigm of truth in modern experience. Yet his claim is problematic since he neglects to name any particular figure or time frame within the vast medieval period. When we think of the medieval concept of truth as correspondence inevitably we think of Thomas Aquinas.

Yet in Being and Time Heidegger identifies Thomas Aquinas doctrine of truth as "adaequatio intellectus et rei."13 When we turn to Heidegger's discussion of truth in Basic Problems we find little in the way of clarification. Apart from the obvious discrepancy the deeper question is whether Heidegger's understanding of the medieval concept of the essence of truth as adequation between created world and divine intellect would nevertheless adequately describe Aquinas view or the medieval doctrine generally.

One might suspect that once the concept of God no longer functioned as the primary ontological ground of what is real then the concept of creation itself would have become superfluous. For Heidegger however the truth is more subtle. The concept of creation did not entirely dissolve but instead was replaced by faith in the power of human reason to forge its own objects. From a modern vantage point the world does not simply appear as a brute fact of nature but as the product of human design. "The theologically conceived order of creation is replaced by the capacity of all objects to be planned by means of worldly reason."14

It should be obvious that such a state of affairs is conducive to maintaining the concept of truth as correctness. Now in modern experience the correspondence which makes for correctness is between concepts and the external world which is the product of human creation. What is it that provides support for the concept of truth as correctness, stripped as it has now become from a more enduring ontological foundation? Heidegger credits the "domination of the obvious." 15 This is to say that apart from a more essential ontological ground which might be revealed by reflective thought, everyday 'common sense' concepts come to prevail. Where 'common sense' prevails over reflective thought it becomes all too obvious that the essential character of truth resides in correctness, and thus it becomes superfluous to make truth into a problem. 
Although he does not develop the theme at this point, elsewhere Heidegger has articulated how the concept of truth as correctness receives massive though inexplicit support from the modern technological 'will to power.' ${ }^{16}$ Given the ubiquitous influence of the modern technological drive toward mastery over nature, it is plausible to think that such a powerful and pervasive force in modern experience becomes in effect 'read back' into our understanding of truth. Truth is thus understood as correctness because the latter supports the interest of technological mastery, an interest to which we as moderns have given our allegiance in a manner which is logically prior to any reflective act of thinking about truth.

Undoubtedly Heidegger could be challenged at this point by arguing the reverse, namely that it is an understanding of truth as correctness, an understanding which is essentially accurate that has made the achievement of modern technology possible to begin with. Thus for Heidegger to implicate the rationality which functions in the development of technology as corrosive to truth is tantamount to a confusion of categories of meaning. Heidegger is in fact aware of this line of criticism. His response to it is to admit that a certain understanding of truth has contributed to the development of technology but to deny that the reverse is not also the case. ${ }^{17}$ The relationship between our modern understanding of truth and technology is a complex issue which can never be exhausted by any simple, one- directional cause-effect type of framework of understanding. The complex relationship between truth and modern technological rationality is an issue which Heidegger has worked hard to articulate.

It might be tempting to think that Heidegger has provided two essentially different answers to the question of why in our modern experience truth is understood as correctness: one in "On the Essence of Truth" ("the domination of the obvious") and the other in "The Question Concerning Technology" (technological rationality). Upon reflection however it is very difficult to distinguish these two arguments. If it is "common sense" in the form of the "domination of the obvious" which in large measure constitutes our modern understanding of truth, that "common sense" is itself historically determined. Our present "common 
sense" experience is one which has been thoroughly pervaded by modern technological rationality. Thus for us moderns "common sense" and technological rationality at least in part coincide.

The above has been put forward by way of attempting to understand the basic structure of Heidegger's historical argument in section 1 of "On the Essence of Truth" ("The Usual concept of Truth"). What can be said by way of critical evaluation of it? It should be clear that Heidegger is challenging the concept of truth as correctness by means of an historical derivation. Thus the concept of truth as correctness is called into question by demonstrating its historically derived character. If Heidegger had claimed such a derivation as a sufficient basis for the falsity of the concept of truth as correctness then he would have obviously succumbed to the genetic fallacy. Yet once again his argument is too complex for this charge to have any justification. His historical derivation of truth as correctness, an exercise which is itself developed in terms of a larger historical context of awareness, is only the first half of a larger argument which will directly examine the character of truth itself. Heidegger's final judgment regarding the character of truth is determined only on the basis of evidence suggested by both aspects of his argument.

The historical derivation which comprises the first half of his argument functions in part to raise doubts concerning truth as correctness. Once truth as correctness is seen as historically derived it appears no longer unimpeachable in character but founded upon that historical context in which it first acquired meaning. In this regard the first part of Heidegger's argument functions in a manner which is not dissimilar to the way in which arguments for ethical relativism attempt to conclude to the relativism of moral values based upon premises which indicate facts concerning cultural relativism. If indeed moral values are culturally and historically derived, then this fact alone is reason to raise fundamental questions concerning the character of moral value even if it is not a sufficient basis to conclude without further argument to the truth of ethical relativism itself.

It is difficult to fault Heidegger on this move. If a serious argument can be made to the effect that once in the history of Western thought the concept of truth meant something very 
different from what it presently means; if the meaning which it once had was one which was given in a more integral relation to fundamental aspects of thinking, experience and life; then there would appear at least to be reason for raising anew the question: 'what is truth?'Yet perhaps we are moving too quickly. Analytical thinkers might very well object to our second premise. One might ask: what difference does it make what the concept of truth once was? Why should it matter philosophically that a concept of truth found in the history of thought was given in an integral union with other concepts such as 'existence,' or 'being,' to say nothing of 'experience and life?' This concept was either false or completely unverifiable, or else Heidegger himself would not find the occasion for exploring the question of truth again today. The essential task for thought is simply to attain the meaning of truth. By indicating the power and depth that the concept of truth had in the medieval world, does Heidegger mean to suggest that this concept was actually correct and accurate? Should we then discard our present concepts of truth and adopt medieval ones?

The fact that Heidegger does not seriously recommend the latter, while at the same time touting the power which medieval concepts of truth once had in a manner which appeals to a deep human longing for an integral union of thought with being, something which no rational concept can ever provide, leaves him open to two charges: obfuscation and irrationalism. Heidegger obfuscates because there is an insidious confusion between the task at hand, which is to define the meaning of truth, and a matter of intellectual history wherein the concept of truth is made intelligible within a determinate historical context of meaning. The latter is quite independent of the question of the meaning of truth itself. His approach is irrational because an appeal is made, albeit veiled by the above act of obfuscation, to sublime feeling rather than strict criterion of intellectual rigor.

In this context Rudolf Carnap's charge that metaphysicians such as Heidegger would have better expressed themselves through music than philosophy ${ }^{18}$ appears to have real force. These are serious charges because they strike at the very center of a claim which is embodied in Heidegger's method: that our philosophical history is or can be intrinsically related to the ongoing creative 
process of philosophical thinking itself. Again and again these charges have been made against Heidegger, and any attempt to defend his methodology must be prepared to offer an adequate defense against them. All too significantly in this regard, Marvin Farber singles out "On The Essence of Truth" as the place in which Heidegger's obfuscating irrationalism reaches its most paradigmatic form. ${ }^{19}$

The attempt to defend against the above charges inevitably takes us beyond the issue of historical methodology to a reflection on the meaning and nature of truth itself. The concept of truth expressed and embodied in our selected texts would radically call into question the presupposition of Heidegger's analyticphenomenological critics that the medieval concept of truth was either accurate or not. Although Heidegger does not make his methodology fully explicit in our selected texts, this methodology is fully consistent with that which is employed in the examination of other issues throughout his work. The issue of Being will serve as an example. Heidegger is clear that the issue of Being, this "most ancient and venerable" of philosophical issues, has time and again been neglected, distorted, co-opted, trivialized, reified, and forgotten in the history of Western thought. Yet he is equally clear that the same tradition or traditions, which have in various ways done violence to the issue of Being have likewise kept the question of Being alive. Hence it was the Being question, even in its concealment and disuse, which has been the driving issue of Western thought.

Whether or not Heidegger is correct in his reading of Western philosophy, it should be obvious that he is operating with quite a subtle and complex concept of truth. This concept becomes quite explicit in sections 6-8 of "On the Essence of Truth." In section 6 Heidegger introduces the concept of truth as aletheia or unconcealment. This concept naturally suggests that untruth should be concealment, yet Heidegger will steadfastly resist this most natural of moves: "Concealment deprives aletheia of disclosure yet it does not render it steresis (privation); rather concealment preserves what is proper to aletheia as its own."20 Here it would be quite tempting to pursue this line of argument in defense of 
Heidegger's historical method yet it would be more fruitful to review his general theory of truth instead.

In all of our selected texts Heidegger is remarkably consistent in accepting correspondence as a fundamental aspect of truth. In The Metaphysical Foundations of Logic he writes: "The definition of truth is the starting point, not yet the answer; it is the point of departure for posing the problem, but is not yet the solution!"2l In Being and Time: "Our analysis takes its departure from the traditional conception of truth and attempts to lay bare the ontological foundations of that conception."22

In each section in which Heidegger articulates his theory of truth he begins with specific everyday examples. In Being and Time the example is given of a picture hanging askew on the wall. In Metaphysical Foundations it is the color of the chalk board. "Let us suppose that someone with his back turned to the wall makes the true assertion that the picture on the wall is hanging askew."23 Heidegger then sets about to examine what it is that would make such a claim true. He concludes that this can be none other than the revealing of the state of affairs of the thing itself, of the picture hanging askew. "Asserting is a way of Being toward the Thing itself that is. And what does one's perceiving of it demonstrate? Nothing else than that this thing is the very entity which one has in mind in one's assertion." ${ }^{24}$ In this manner Heidegger argues that the primary locus of truth does not lie in assertions, judgments, claims, or ideas but rather in the actual making present of a certain state of affairs. Heidegger famously credits the Greeks and in particular Aristotle for a dim and partial awareness, one quickly covered over by formal theories of this primordial essence of truth as "unconcealment."

Western thinking in its beginning conceived this open region as ta alethea, the unconcealed. If we translate alethea as "unconceal-ment" rather than truth this translation is not merely more literal; it contains the directive to rethink the ordinary concept of truth in the sense of the correctness of statements and to rethink it back to that still 
uncomprehended disclosedness and disclosure of beings. ${ }^{25}$

The character of Heidegger's position should be clear enough. Assertions, claims and judgments are founded modes of being, they are founded upon a more primary disclosure of a state of affairs which is only in the 'second moment' captured in the form of a determinate claim. It would therefore be superficial and shortsighted to identify the essence of truth with judgments. We should rather understand the essence of truth to be present in disclosure which forms the basis of judgments. Thus in the statement "The picture on the wall is hanging askew," truth is present in the statement in only a limited or derived sense. The primary locus of truth is present only in the actual experience of viewing the position of the picture.

The issue discussed above goes beyond that of how to define the essence of truth. In sections of Being and Time other than 44, and in Basic Problems as well, Heidegger goes to great length to attempt to demonstrate how language is not a primary locus of truth; meaning does not arise by amassing atomistic units to form a whole; rather language itself is a result of significance, which is a fundamental structure of human existence ${ }^{26}$. Thus Heidegger's understanding of truth as disclosure exhibited thus far has wider significance in terms of his general theory of meaning.

Yet specifically in terms of the issue of whether correspondence adequately captures the essence of truth, it might be claimed that the understanding of truth exhibited thus far would be open to the charge of equivocation. Obviously truth is present not simply in a disclosure of any state of affairs at all but rather in a disclosure of the precise state of affairs indicated in an assertion or a judgment. Truth is not contained in the picture hanging askew or even in the disclosure of this state of affairs, but rather in the fact that this state of affairs corresponds precisely to a previous judgment. Thus it might be argued that any attempt to reduce to a single aspect the complex way in which thinking and being are united in the form of judgment must result in solipsism.

In fact Heidegger's position is not actually open to this line of objection at all. In "On the Essence of Truth" the question is raised 
as to what is meant by "true gold." The claim that the true is essentially the actual is easily dismissed since false gold is just as actual as the true. Thus "true gold" can only mean a type of metal which corresponds with a preconceived concept of gold. "Genuine gold is that actual gold the actuality of which is in accordance with what always and in advance we 'properly' mean by gold."27

Once again Heidegger is well aware of the centrality of the concept of correspondence to truth, yet he will resist the temptation to identify the essence of truth with correspondence. His strategy consists instead of relentlessly probing the issue of what such correspondence can mean ontologically. In "On the Essence of Truth," Heidegger began his inquiry by asking how it is possible that intellect and thing, two dissimilar modes of being can at all correspond. If we were to understand this question as epistemological then we should rightly conclude as Marvin Farber does, that Heidegger is here engaged in a type of pretense, pretending originality for a question which has already been explored in abundant literature. ${ }^{28}$ In fact Heidegger's question is ontological. Any attempt to put this question on a continuum with the abundant epistemological literature on the subject can only result in an essential misunderstanding. Moreover Heidegger's exploration of this ontological question is consistent throughout most of his writings on truth. It is in this ontological dimension that what is unique in Heidegger's theory of truth is contained.

How then is correspondence possible ontologically? First, Heidegger would adamantly deny that such correspondence can be explained in terms of the traditional Cartesian notion of an isolated subject over and against an objective world. If this were a correct description of the ontological starting point for the act of knowledge, then correspondence would not be at all possible. It should be clear that the issue goes beyond that of knowledge, or rather it is prior to knowledge, having to do with that of the fundamental manner in which human beings are in a world ontologically. For Heidegger human beings are not simply present in a world as objects in a container, but rather being-in-a-world belongs to the basic ontological constitution of being human. "Being in" is thus the formal existential expression for the Being of Dasein, which has Being-in-the-world as its essential state."29 
What Heidegger is rejecting in the traditional notion of truth as correspondence is the claim that truth is attained to the extent that an isolated and detached subject escapes the "cabinet" of consciousness to apprehend something which is external to it. Rather it should be said that human beings in their "first moment" already "dwell" in a world. It is only in terms of that "concernful," " circumspective" "absorption" in a world that any specific truth claims can be made. As Heidegger says in The Metaphysical Foundations of Logic: "We are rather always comporting ourselves towards the beings around us. Statements do not first bring about this relation, but rather the reverse is true. Statements are first possible on the basis of an always latent comportment to beings. ....We can say that making statements about $\mathrm{X}$ is only possible on the basis of having to do with $X .{ }^{, 30}$

One significant aspect of Heidegger's understanding of truth is that it can to some extent be translated into modern epistemological language. From an epistemological perspective it is superficial and inaccurate to identify the essence of truth with correspondence. This is because correspondence presupposes a larger framework of meaning as its basis and ground. "That is a statement about $X$ is true only because our dealing with that $X$ already has a certain kind of truth." ${ }_{31}$ Later on the same page Heidegger writes: "Propositional truth is more primordially rooted, rooted in the already being by things. The latter occurs 'already,' before making statements since when? Always already! Already, that is, insofar as and as long as Dasein exists." 32

In the example given earlier, "The picture on the wall is hanging askew," the very possibility of correspondence presupposes an anterior familiarity with the world, language, specific meanings to the words used, visual perception etc. Thus to identify the essence of truth with correspondence would not be accurate from an epistemological point of view.

With this short overview of Heidegger's positive concept of truth we are now in a better position to defend against the kind of specific charges leveled against Heidegger's historical approach to truth cited previously. The essential character of these charges was expressed in the question: 'what difference does it make what the concept of truth once was?' In indicating the essential 
connection which the medieval concept of truth had with experience and life in contrast to the modern one Heidegger is not appealing to irrational instinct or blind feeling. What is presupposed in this charge is that the medieval concept of truth was simply wrong. This presupposition is however too simplistic to have value. As we have seen, there are considered reasons why our modern concept of truth as correctness is epistemologically and ontologically inaccurate. Likewise in attempting to establish an enduring basis for correspondence the medievals understood that there are deep ontological grounds for our human experience of truth which cannot be simply expressed in terms of correctness. Above all the medievals understood that there is indeed a primordial connection of truth with Being.

\section{Notes}

1. Cf. Walter Biemal, Martin Heidegger an Illustrated Study trans J. L. Mehta (New York: Harcourt Brace and Jovanovich, 1976) Chap. 1.

2. Cf. William J. Richardson, Heidegger Through Phenomenology to Thought (Martinus Nijhoff/The Hague, 1963) p. 22

3. Cf. Hubert L. Dreyfus, Being in the World (Cambridge: The Mitt Press, 1991) pave-ix.

4. Cf. Martin Heidegger, History of the Concept of Time (Indiana: Indiana University Press, 1985) Chap. 1.

5. Martin Heidegger, Being and Time trans. John Macquarie and Edward Robinson (New York: Harper and Row, 1962) p. 42.

6. Heidegger, Being and Time, op. ct. p. 43.

7. Reiner Schurmann, Heidegger on Being and Acting: From Principles to Anarchy (Indiana: Indiana University Press, 1990) p. 11.

8. Cf. Ibid., p. 43. and Basic Problems of Phenomenology (Indiana: Indiana University Press, 1998) Chap. 2-3.

9. Cf. Ludwig Wittgenstein, Philosophical Investigations, tr. by G.E.M. Anscome (New York: Macmillian, 1958) p. 190-229.

10. Heidegger, Being and Time, op. cit., P. 214

11. Martin Heidegger, "On the Essence of Truth," in Basic Writings, David Farrell ed. (New York: Harper and Row, 1977) p. 120.

12. Ibid., p. 121.

13. Heidegger Being and Time, op. cit. p. 214.

14. Heidegger, "On the Essence of Truth," op. cit., p.121.

15. Ibid. 
16. Cf. Heidegger, "The Question Concerning Technology," in Basic Writings, op. cit.

17. Cf. Ibid.

18. Cf. Simon Critchley Continental Philosophy, (Oxford: Oxford University Press, 2001) p. 96.

19. Cf. Marvin Farber, "Heidegger on the Essence of Truth," in Philosophy and Phenomenological Research, Volume 18, Issue 4 (Jun, 1958) p. 531.

20. Heidegger, "On the Essence of Truth," op. cit. p. 132.

21. Martin Heidegger, The Metaphysical Foundations of Logic, (Indiana University Press, 1992) p 125.

22. Heidegger, Being and Time, op. cit., p. 257.

23. Ibid., p. 206.

24. Ibid., p. 260-261.

25. Heidegger, "On the Essence of Truth," op. cit. p. 127.

26. Cf. Heidegger, Being and Time, op. cit., p.114-122 and Basic Problems of Phenomenology tr. by Albert Hofsteader (Indiana: Indiana University Press, 1982) p. 205-224.

27. Ibid., p. 119.

28. Marvin Farber, op. cit. p. 256.

29. Heidegger, Being and Time, op. cit., p. 80.

30. Heidegger, The Metaphysical Foundations of Logic, op. cit., p. 206.

31. Ibid, p. 127.

32. Ibid. 